Discussion Paper No. 14-007

\title{
Chinese Pension Fund Investment Efficiency - Evidence from CNCSSF Stock Holdings
}

Gunnar Lang, Yu Shen, and Xian Xu

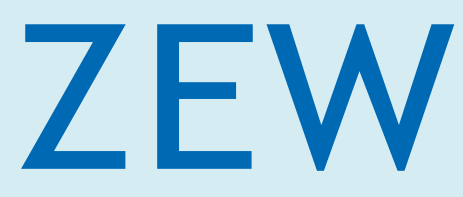

Zentrum für Europäische Wirtschaftsforschung $\mathrm{GmbH}$ Centre for European Economic Research 
Discussion Paper No. 14-007

\title{
Chinese Pension Fund Investment Efficiency - Evidence from CNCSSF Stock Holdings
}

\author{
Gunnar Lang, Yu Shen, and Xian Xu
}

Download this ZEW Discussion Paper from our ftp server:

http://ftp.zew.de/pub/zew-docs/dp/dp14007.pdf

Die Discussion Papers dienen einer möglichst schnellen Verbreitung von neueren Forschungsarbeiten des ZEW. Die Beiträge liegen in alleiniger Verantwortung der Autoren und stellen nicht notwendigerweise die Meinung des ZEW dar.

Discussion Papers are intended to make results of ZEW research promptly available to other economists in order to encourage discussion and suggestions for revisions. The authors are solely responsible for the contents which do not necessarily represent the opinion of the ZEW. 


\section{Chinese Pension Fund Investment Efficiency - Evidence from CNCSSF Stock Holdings}

Gunnar Lang, Centre for European Economic Research (ZEW), Germany

Email: lang@zew.de

Tel: 0049-621-1235-372

Address: L7, 1, 68161 Mannheim, Germany

Yu Shen, Financial Research Center, Fudan University, China

Email: shenyu2071@163.com

Tel: 0086-21-65100977

Address: 220 Handan Road, 200433, Shanghai, PR. China

Xian Xu, School of Economics, Fudan University, China

Email: xianxu@fudan.edu.cn

Tel: 0086-21-55665332

Address: 600 Guoquan Road, 200433, Shanghai, PR. China

Abstract: China's pension system is facing a large gap of more than one trillion RMB. The investment efficiency of the social security fund therefore receives widespread attention in academic circles. We collected data of stocks held by the Chinese National Council for Social Security Fund (CNCSSF) from 2004 to 2012 to research the stocks' investment efficiency, distinguishing between direct investment by the CNCSSF and entrusted investment by fund companies. The results indicate that both components of the Chinese Social Security Fund investment have efficiency drawbacks. Direct investment by the CNCSSF does not obtain excess returns, while entrusted investment reaches an annual excess return of 4.32 percent because more private information is available to fund companies than to the CNCSSF during asset allocation. Further analyses of this paper find, however, that the Chinese Social Security Fund has a significant market-stabilizing effect, which is almost three times stronger than the market-stabilizing effect of entrusted investment. In general, entrusted investment performs better than direct investment with regard to investment efficiency, while direct investment performs better in terms of market stabilization.

JEL-Classification: G11, G14, G23

Keywords: Pension fund investment, Performance evaluation, Chinese pension funds

We thank Zhuomiao Chen and Anna-Lena Huthmacher for very helpful research assistance. 


\section{Introduction}

From the 1980s onward, the majority of the literature on social security funds has focused on fund returns, finding that social security funds are not able to obtain excess market returns, which in turn reflects the efficient market hypothesis in the US and the UK. Current research, however, has used a larger sample and advanced methods to show that it is possible to obtain excess market returns. This paper focuses on market stabilization and investor return perspectives to scrutinize previous research. The majority of the research indicates that pension fund returns cannot exceed market returns, stated for example by Beebower and Bergstrom (1977), who studied the portfolios of 148 pension funds in the United States from 1966-1975. The authors used the CAPM model to calculate the sample's Jensen alpha and they found that the pension funds' returns are lower than the S\&P 500 by 144 percentage points. Similarly, Brinson, Hood and Beebower (1986) analyzed 91 US pension funds and found that their return was lower than the S\&P 500 by 1.1 percent. Ippolito and Turner (1987) point out that the small sample size of pension funds will affect statistical tests; a survival bias could have a direct impact on the calculation results. To solve this problem, Ippolito and Turner selected a larger sample of 1526 US pension funds whose returns were lower than the S\&P 500 by only 0.44 percent. Since the 1980 s both pension size and the number of pension funds in the United States have increased, while pension fund returns have not. Lakonishok, Shleifer and Vishney (1992), for instance, selected 769 pension funds in the United States from the 1980s. These funds' returns were lower than the S\&P 500 by 1.3 percent. The same holds true for the UK. Here, Thomas and Tonks (2001) selected 2175 pension funds from 1984 to 1997, showing that the pension funds do not achieve excess returns. Gregory and Tonks (2004) demonstrate that the English pension funds they studied have a home bias, but were still unable to achieve extra market returns.

In order to identify the reasons for the low investment income of pension funds, many researchers analyze investment ability and asset allocation. For example, Coggin, 
Fabozzi and Rahman (1993) analyzed a sample of 71 pension funds in the United States, from the angle of the fund managers' stock-picking and timing ability. They found that pension funds have a positive stock-picking ability. However, their timing ability is low and therefore reduces investment return. Blake, Lehmann and Timmermann (1999) also show that the fund managers' stock-picking and timing ability make a negative contribution towards 364 selected English pension funds from 1986-1994.

The idea that pension funds cannot obtain extra market returns confirms the "efficient market hypothesis", which suggests that timely information will affect price, and that investors cannot always achieve excess returns (Fama, 1970). To the contrary, many scholars in recent years have found that pension funds are able to obtain excess returns. Elton, Gruber and Blake (2006), e.g., find that the 401k plan in the United States, which is entrusted to mutual funds, has a higher annual average return than that of the stock index by 0.31 percent. Bauer et al. (2010) selected 463 pension funds in the United States from 1990 to 2006 and found that the observed pension funds taken together do not obtain excess returns; however, a few individual small-scale pension funds are able to achieve excess returns of 3 percent.

Current studies identify three main reasons for pension funds' ability to generate excess returns: centralized investment, active investment and private information arbitrage. Firstly, as professional institutional investors, funds (including pension funds) have a distinct advantage in investment techniques and information gathering methods and are therefore able to obtain higher returns using centralized investment (Levy and Livingston, 1995). Nieuwerburgh and Veldkamp (2010) found that investment ability has an increasing returns-to-scale effect; thus fund managers will select a centralized investment strategy. Investment diversification, on the other hand, may decrease risk, but may not achieve the same returns. Kacperczyk et al. (2005) found that a professional analysis can enhance performance considerably. They constructed an industry concentration indicator and found that mutual fund returns are positively correlated with portfolio concentration. 
The second reason is active investment. Wermers (2000) states that funds that are highly active each year can achieve 1.3 percent in excess returns. Wermers (2003) used the tracking error of the active investment capacity of the fund portfolio and the S\&P 500 index to measure the fund's active investment and confirms that active investment funds have a greater stock-picking ability. Cremers and Petajisto (2009) used the deviation of fund portfolio and index fund to build active investment indicators. They show that active investment in the fund can lead to excess returns. The greater the deviation of the fund portfolio from the index, the higher the achievable returns can be. Brands et al. (2006), Cremers and Petajisto (2009) used the Euclidean distance method to calculate the active investment indicator of the fund and point out that an active investment fund's performance increases with a higher indicator.

The third reason for excess returns is private information arbitrage. In an imperfect market, asset information distribution is unbalanced. In other words, some financial actors have more useful information about an asset than others. Informed traders may use this private information to generate higher returns (Merton, 1987). Fund managers, through a variety of bonus incentives, will increase their efforts to study market trends, collect stocks' private information, and will therefore benefit from private information. Teoh et al., (2009), Amihud and Geyonko (2013) used the $\mathrm{R}^{2}$ indicator of fund returns and market returns to measure the mutual funds' access to private information. They hypothesize that the $\left(1-\mathrm{R}^{2}\right)$ indicator includes mutual funds' heterogeneity information, which cannot be observed. The higher $\left(1-\mathrm{R}^{2}\right)$, the more private information a mutual fund possesses. Amihud and Geyonko (2013) found empirical evidence that funds with more private information are able to obtain excess returns of 2.5 percent per year. Luo (2011) and Shen et al. (2013) also confirm a positive correlation between private information and excess returns in China.

Chinese scholars have not yet systematically analyzed the rate of return of social security funds. Existing research usually consists of small sample sizes, a short time span and methods which are not of a high scientific standard and hence make it 
difficult to control for the fund's investment risk. Therefore, Chinese research often results in the conclusion that there is a large sample shortcoming. Wang (2010), for instance, selected 29 CNSSF portfolios from 2005-2010 and byusing the CAPM model, suggests that the CNSSF has a sound stock-selection ability. Liu and Tang (2011) studied the 2009-2010 quarterly CNSSF data and point out that the CNSSF has obvious positive effects on companies' share price in the short term and that listed companies with CNSSF holdings have significantly higher share price returns. Nevertheless, there are many important issues which remain unanswered in China. Is the CNSSF able to perform better than the market and can it achieve excess returns? Is there any performance difference between the CNCSSF direct stock investment and entrusted investment? Is CNSSF return related to the access to inside market information and to asset allocation? We aim to select a larger sample and longer time span than the existing studies by using the Fama and French (1993), Carhart (1997) four-factor model, as well as a panel data analysis to examine these issues and to provide a deeper understanding of CNSSF investment efficiency.

In addition, the market-stabilizing effect of the social security fund has been proven. Guercio and Tkac (2002) found that market-oriented operations of pension funds in the market act as "automatic stabilizers". As a result there is a linear relationship between liquidity and pension fund performance. Pension funds have the ability to select fund managers, they can retract investments when fund performance is bad, and can, conversely, increase investment when fund performance is good. Pension funds entrust investors and put pressure on fund managers to secure lower risk and higher returns, which can decrease market system risk and stabilize the market. Bohl (2006) suggests that Polish pension funds affect the stock market index in a way that reduces the degree of fluctuations in the market. Although He (2007), Sheng (2008), Cai and Song (2010) point out that institutional investors in China have a market-stabilizing function, there is no evidence that the CNSSF can stabilize the stock market. Most importantly, no study so far has linked the low return of CNSSF to a marketstabilizing function. A negative influence of the CNSSF's market-stabilizing function 
on returns would explain CNSSF inefficiency. Past research has entirely neglected the fact that the CNSSF places both direct and entrusted investments, and fails to distinguish between the two investment styles. This paper examines the efficiency of CNSSF investment, carries out a comparative analysis of direct investment and entrusted investment returns and these investment types' ability to stabilize the market.

\section{Data and Research Design}

\subsection{Data selection}

The CNCSSF was established in August 2000 to become the operational statutory body of the CNSSF. In order to improve the investment performance of the CNSSF, the CNCSSF reached an agreement with the People's Bank of China, the Ministry of Finance and the China Securities Regulatory Commission by the end of 2003,. It commissioned six fund management companies to be entrusted investors of the CNSSF. As of the end of 2012, the number of commissioned fund management companies stands at eighteen. The CNSSF can place investments either through these 18 entrusted companies or through the CNCSSF itself. The investment channels include bonds, trusts, stocks, funds, equity investments, asset securitization and equity investment funds. However, the CNCSSF does not disclose portfolio investment details, making it difficult to obtain information about the asset allocation of the CNSSF.

The Chinese disclosure obligation of listed companies, however, gives us access to the CNSSF's equity investments. Since listed companies are required to disclose the number of their shareholders and the shareholders' names, we have access to shareholder information and select the information according to "CNSSF combination", "CNSSF *** portfolio" in order to collect the social security fund portfolio investment details. To ensure the validity of the entrusted investment details, we used the disclosed CNSSF portfolio information provided by the CNCSSF website in order to verify and complement the CNSSF investment details (see Table 1). We distinguish between direct investments and entrusted CNSFF investments. All the data 
stems from the Wind database.

From the Wind database we obtained CNCSSF holdings data, stock yield, the size of the stock assets, financial data, the return of net asset value, and scale data from securities companies. In order to ensure data quality, we randomly selected sample data and we also used the RESSET database (RESSET) to compare differences in the data. If there was a discrepancy between the Wind database and the RESSET database, ${ }^{1}$ we downloaded the annual reports from the websites of Shanghai Stock Exchange and Shenzhen Stock Exchange to review the statements. CNSSF Annual Report data stems from the CNCSSF website.

Table 1 shows CNSSF direct investment and entrusted investment from 2004 to 2012. The entrusted companies commissioned by the CNCSSF possessed at least 3 and up to 9 portfolios they invested in. Boshi Fund, Huaxia Fund and Harvest Fund managed 7 CNSSF portfolios, the other fund companies managed 3-6 CNSSF portfolios. The state-owned company China International Capital Corporation (CICC) managed 3 CNSSF portfolios. In general, the main types of CNSSF investments included bonds and the Shanghai and Shenzhen index funds so as to control the investment risk. However, such investment channels result in lower returns. In order to obtain higher gains, the CNCSSF allowed part of the fund's portfolio to build up stock funds and stock-and-bond mixed active funds. We used these equity and hybrid active investment funds and attempted to analyze whether there is an efficiency difference between direct investment and entrusted investment.

\footnotetext{
${ }^{1}$ Both RESSET and Wind database are famous databases in China; more than $90 \%$ of research papers use the two databases. RESSET data is collected by Tsinghua University Economic and Management school, while Wind is operated by a business data company, most investment institutions use Wind data for data collection.
} 
Table 1 CNSSF Managed by Mutual Funds

\begin{tabular}{lllll}
\hline \hline Fund company & $\begin{array}{l}\text { Portfolio } \\
\text { number }\end{array}$ & \multicolumn{3}{c}{ Portfolio code names provided by CNCSSF } \\
\hline CNCSSF & 5 & $001,002,004,005,006$ \\
Boshi Fund & 9 & $102,103,108,202,402,501,702,802,902$ \\
Huaxia Fund & 7 & $007,107,203,801,901$ \\
Jiashi Fund & 7 & $106,206,306,406,504,602,706$ \\
Penghua Fund & 6 & $104,204,304,404,503,704$ \\
Changsheng Fund & 6 & $105,205,305,405,603,705$ \\
Yifangda Fund & 5 & $109,407,502,601,707$ \\
Nanfang Fund & 5 & $101,201,301,401,701$ & \\
Zhaoshang Fund & 4 & $110,408,604,708$ & \\
Guotai Fund & 3 & $11,409,709$ & \\
Zhongjin Corp. & 3 & $112,410,710$ & \\
\hline
\end{tabular}

\subsection{Research Design}

Firstly, can the CNSSF's stock investment achieve excess returns? From the data collected, we can observe that the CNSSF prefers to invest partially in share funds and hybrid funds and is thus exposed to more risk. According to classical investment theory (Fama and French, 1993), if the CNSSF achieves extra market gains after the risk-adjusted market returns, the investment can be regarded as efficient, otherwise it is inefficient. We use Fama and French (1993) and Carhart (1997) models in this paper for a risk adjustment of the CNSSF's portfolio. The average excess return of the CNSSF amounts to 3.76 percent, however this amount is not significant. A more detailed analysis of the data reveals that entrusted investment amounts to 4.32 percent while direct investment was not able to achieve excess return. This scenario reveals that it is better to entrust investment than to invest directly. But can any entrusted institution outperform direct investment? In other words, which entrusted institution performs better? We used Carhart's four-factor model to analyze investment efficiency in China. The results show that Nanfang Fund excess returns are the highest at 17.1 percent in one year, followed by Yifangda Fund at 9.56 percent, Zhaoshang Fund at 9.12 percent, and Huaxia Fund at 5.65 percent. As for Zhongjin Fund, its return was below expectations at -22.7 percent. The remaining funds' returns, for example Changsheng Fund, Jiashi Fund and Penghua Fund, do not differ from 
direct investment returns. These results show that 4 out of 10 entrusted investment funds are able to achieve excess market returns, which means that the CNSSF has to select certain entrusted investment funds to work with.

Secondly, why do the investments of CNSSF have different rates of return? How does this difference come about? In a market with incomplete information, investors with inside information are able to produce excess market returns (Merton, 1987). The question is hence whether the CNCSSF, as a national organization, has access to inside market information. The general public is interested in the CNCSSF's overall investment because they believe that the CNCSSF has access to such information. If this is true, can this information provide for extra market gains? We investigated these questions by using the Amihud and Geyonko (2013) private information index and control for depth, width and risk of asset allocation. The results show that the CNCSSF does indeed have private information which allows for extra returns. If the amount of private information grows by 1 unit, excess return increases by 0.477 percent. This finding proves the theory of Merton (1987). However, access to inside market information results in an endogenous reverse causality problem. This paper uses mutual funds' average access to inside market information as an instrumental variable of the CNSSF, and a panel of two-stage instrumental variables to conclude that inside market information is an important factor leading to extra market gains for the CNCSSF. We also suggest that the CNCSSF has less inside information on direct investment, indicating that the institution has no information advantage over entrusted investors regarding this investment type. This again explains why direct investment has lower returns compared to entrusted investment funds.

Thirdly, does the CNSSF as a special fund have a stabilizing effect on the stock market? To analyze how the CNSSF affects the Chinese stock market, Graph 1 shows the relationship between the quarterly CNSSF stock value and the development of the Shanghai-Shenzhen Securities Composite Index (SSSCI). Graph 1 indicates that the SSSCI and the CNSSF move in tandem with a slight delay. As an example, the SSSCI reached its peak in December 2007, while the CNSSF began to sell in June 2007. In 
September 2008, the CNSSF started to buy in and three months later the SSSCI began to grow; the CNSSF's share in the stock market increased by 17 percent during this period. It is possible that the CNSSF sacrifices its gains for market stabilization, given that it has lower returns as analyzed below, and is positively correlated with the SSSCI. We therefore developed a cash flow index to analyze the correlation between the cash movement of the CNSSF and stock index volatility. The results indicate that cash movement and stock index volatility have a negative correlation and every 1 percent increase in cash flow results in a 0.114 percent decrease in volatility.

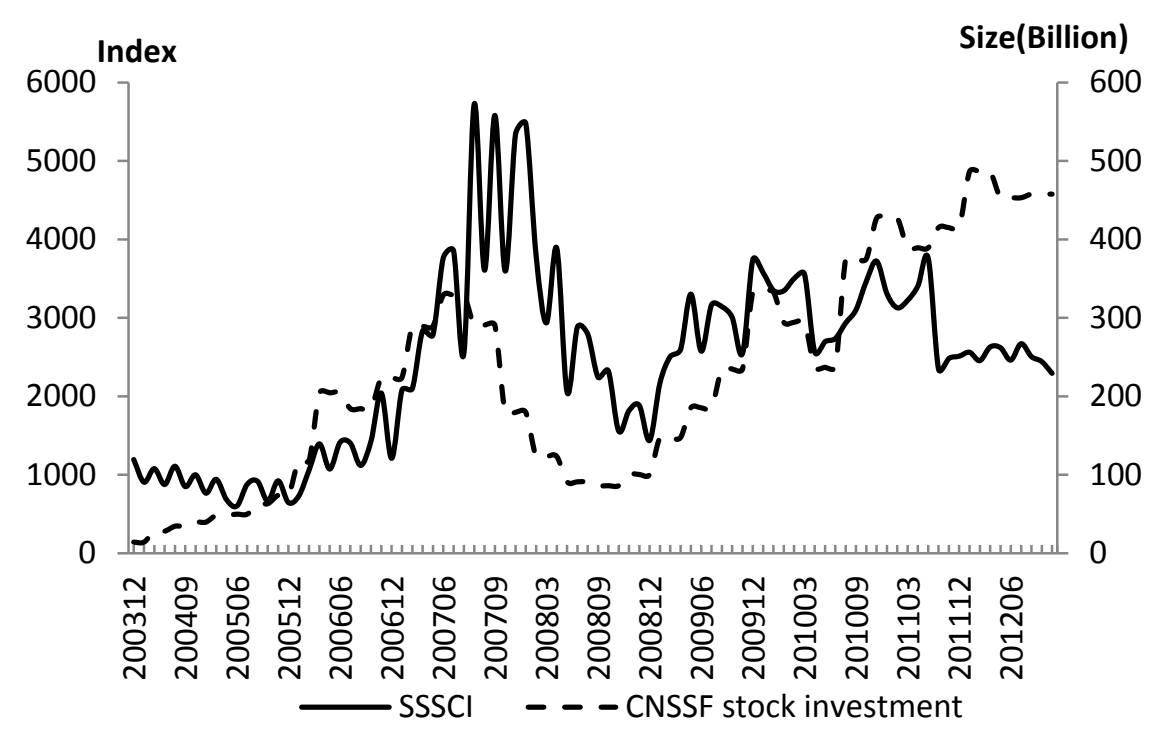

Graph1: Trends of the CNSSF stock investment and the SSSCI (CNSSF stock investment, SSSCI)

To find out whether stock market stabilization is the reason for the CNCSSF's lower stock investment return, we analyzed the CNCSSF's effect on market stability and we suggest that there is a difference between direct and entrusted investment. Direct investment has a greater impact on stabilizing the market, while entrusted investment is geared towards higher returns. There is no doubt that the Chinese National Social Security Fund (CNSSF) plays an important role in stabilizing the Chinese capital market. However, China needs to create a healthy and liberal capital market in the long run. This requires the Chinese government to reduce its role in the capital market. Through marketization it increases the return of the CNSSF and meanwhile helps 
develop a healthy capital market, from which both the CNCSSF and mutual fund investors can benefit.

\section{Empirical Analysis}

\subsection{Variable Construction}

\subsubsection{Portfolio return}

We followed the method used by Wermers (2003), Cremers and Petajisto (2009), using weight sum returns to obtain the CNSSF portfolio return, resulting in:

$$
\begin{gathered}
R_{i, t}=\left(P_{i, t}-P_{i, t-1}+\operatorname{Divd}_{i, t-1}\right) / P_{i, t-1} \\
\operatorname{Pr}_{t}=\sum w_{j, t} R_{j, t}
\end{gathered}
$$

where $P_{i, t}$ is the price of stock $i$ in portfolio at time $t, D i v d_{i, t}$ is the dividends of stock $i$ from $\mathrm{t}-1$ to $\mathrm{t} . w_{j, t}$ is the weight of the stock $j$ in portfolio at time $t$.

\subsubsection{Depth and width of asset allocation}

Referring to the Pollet and Wilson (2008) portfolio disparity index, we used the regularly reported stock assets disclosure of the CNSSF portfolios and defined the portfolio breadth indicators (Width) as the natural logarithm of the sum of each portfolio stock amount. The combination of depth (Depth) is measured by the weighted holding share of each portfolio, expressed by the formula:

$$
\begin{aligned}
& \text { Width }_{i}=\log \left(1+n_{i}\right) \\
& \text { Depth }_{i}=\sum_{k=1}^{n} w_{i k} c_{i k}
\end{aligned}
$$

$n_{i}$ is the amount of stock in fund $i, w_{i k}$ is the proportion of stock $k$ in the fund portfolio, $c_{i k}$ is the proportion of stock $k$ of total market capitalization.

\subsubsection{Private information}

Following Amihud and Geyonko (2013), Shen et al. (2013), we used the four-factor model of Carhart (1997) in order to measure the relevant fluctuations of the funds by the fitting degree $\mathrm{R}^{2}$, which we obtained from the regression of the return of funds. 
The authors hypothesize that the $\left(1-\mathrm{R}^{2}\right)$ indicator includes mutual funds' heterogeneity information, which cannot be observed. A higher $\left(1-\mathrm{R}^{2}\right)$ implies a greater amount of private information (Teoh et al., 2009). We use PI (private information) to measure the fund's inside market information.

\subsubsection{Other variables}

According to Chen et al. (2004), we selected the control variables affecting the fund's performance: fund size (Size), equal to the natural logarithm of the quarter net total value; fund family size (Fsize), equal to the natural logarithm of the quarter net total value of all funds controlled by the same holding fund; fund asset allocation risk (Beta), measured by the four-factor model of the past 36-month rolling market factor coefficients obtained by the regression model (Carhart,1997).

\subsection{Sample description}

Table 2 shows the descriptive statistics of the relevant variables. The median and the mean of the CNSSF asset allocation depth indicators are close, indicating that the depth distribution of the CNSSF asset allocation is uniform. Width indicates that the asset allocation is quite diverse. The average social security fund portfolio selects 15 stocks, the smallest fund portfolio consists of only one stock, the largest portfolio contains 72 stocks. The mean of the amount of private information (PI) is 0.431 , almost equal to the median, indicating that the fund portfolio has access to more private information. Asset allocation risk of individual stocks is very close to 1 , but the gap between the minimum and maximum values also show that the CNSSF portfolios' appetite for risk in asset allocation is quite diverse. From 2004 to 2012, the average size of the CNSSF portfolios investing in stocks increased from 15.8 billion yuan to 1,263 billion yuan. The average-sized funds reached 136.4 billion yuan by fund family. It cannot be concluded that the CNCSSF usually entrusts large fund companies. 
Table 2

Variables description

\begin{tabular}{llllll}
\hline \hline Variable & Mean & Median & Min & Max & Std. \\
\hline Depth & 2.478 & 2.313 & 0.120 & 9.500 & 1.295 \\
Width & 14.87 & 13 & 1 & 72 & 11.1 \\
PI & 0.431 & 0.432 & 0.153 & 0.749 & 0.093 \\
Beta & 0.998 & 0.986 & 0.239 & 2.036 & 0.174 \\
Size(billion) & 1.263 & 0.6263 & 0.00513 & 15.88 & 1.718 \\
Fsize(billion) & 136.418 & 71.761 & 5.137 & 158.755 & 175.849 \\
\hline \hline
\end{tabular}

We compared direct investment returns and entrusted investment returns of CNCSSF using a t-test. The test results are reported in Table 3. Taking into account that the yield data may not follow a normal distribution, the non-parametric Wilcoxon pvalues are also reported.

The results in Table 3 show that the average monthly return of direct investment is 1.18 percent, while the average monthly return of entrusted investment is 2.53 percent. The difference is thus 1.35 percent. The result is significant at the 1-percent level, the $\mathrm{t}$ value is 3.17 and it therefore passes the Wilcoxon test. The average direct investment return is significantly lower than the average return of entrusted investment. For a more detailed analysis, we took a closer look at the differences between the returns of direct investment and entrusted investment, and tested whether the differences are statistically significant. The only funds that do not pass the $t$ value test are China Merchants Fund and CICC; the $t$ values of the remaining funds pass the test. The initial results in Table 3 confirm that investment efficiency is lower for direct investment compared to entrusted investment, but the p-value of Huaxia Fund and South Fund is not statistically significant. It should therefore be further researched by means of a time series angle-depth study. 
Table 3 Monthly Return Difference Test

\begin{tabular}{lllll}
\hline \hline & $\begin{array}{l}\text { Return } \\
(\%)\end{array}$ & $\begin{array}{l}\text { Diff. } \\
(\%)\end{array}$ & $t$ value & Wilcox.p value \\
\hline Direct operation invest. & 1.180 & & & \\
Entrust Invest. & 2.532 & 1.352 & $4.23^{* * *}$ & 0.001 \\
Boshi Fund & 2.274 & 1.094 & $3.17^{* * *}$ & 0.005 \\
Huaxia Fund & 2.934 & 1.754 & $3.11 * * *$ & 0.012 \\
Jiashi Fund & 2.21 & 1.03 & $2.23^{* *}$ & 0.281 \\
Penghua Fund & 2.60 & 1.42 & $3.58^{* * *}$ & 0.003 \\
Changsheng Fund & 2.697 & 1.517 & $3.44^{* * *}$ & 0.001 \\
Yifangda Fund & 2.031 & 0.851 & $1.69^{*}$ & 0.3167 \\
Nanfang Fund & 2.956 & 1.776 & $4.54^{* * *}$ & 0.0016 \\
Zhaoshang Fund & 3.597 & 2.417 & $4.89^{* * *}$ & $<0.001$ \\
Guotai Fund & 1.6901 & 0.510 & 1.223 & 0.7567 \\
ZhongjinCorporatation & 2.024 & 0.844 & 1.15 & 0.067 \\
\hline \hline
\end{tabular}

$*, * *, * * *$ denote significance at 10\%, 5\%, 1\% level respectively.

\subsection{Investment efficiency}

According to classical investment theory, a fund's investment income and investment risk are closely related. A high yield is not always the result of high efficiency; it may also be a compensation for great risk. The risk-adjusted return on investment can measure the level of efficiency of the investment. We used the Fama and French (1993), Carhart (1997) four-factor model to measure the risk-adjusted CNSSF portfolio returns. Empirical research generally believes that assets' return can be explained by the four-factor model. The intercept (alpha) reflects the abnormal returns which the risk factors cannot explain. If alpha is statistically significantly greater than 0 , the fund's investment portfolio is able to achieve excess returns and fund managers have superior stock-picking ability and greater investment efficiency. Conversely, if the alpha is statistically significantly smaller than 0 , the fund manager has low investment efficiency. The four-factor model is expressed as follows:

$$
R_{p t}-R_{f t}=\alpha_{i}+\beta_{1}\left(R_{m t}-R_{f t}\right)+\beta_{2} S M B_{i t}+\beta_{3} H M L_{i t}+\beta_{4} M O M_{i t}+\varepsilon_{i t}(5)
$$

$R_{m}$ is the reinvested consolidated monthly market rate of return of market 
capitalization-weighted cash dividends; $\mathrm{R}_{f}$ is the risk-free rate equal to the one-year deposit interest rate divided by 12; SMB, HML are scale factor and book-to-market ratio factor, in line with Fama and French (1993); MOM is the structure momentum factor, in line with Carhart (1997). The regression results and Newey-West adjusted tvalues are reported in Table 4. Panel A is equally weighted, Panel B is weighted by the total net value, and Panel $\mathrm{C}$ is weighted by the sum of the flow of funds.

The regression results of the four-factor model and adjusted t values using the NeweyWest method are reported in Table 4. We use the Newey-West method because the regression residual may be correlated. It also can control for the residual autocorrelation of the regression to obtain a more accurate $t$ value. The Adj. $\mathrm{R}^{2}$ of all models in Table 4 are greater than 0.6 , the overall sample Adj. $\mathrm{R}^{2}$ being 0.965 . The sample of entrusted investment reaches 0.963 and the great majority of the risk factors of the model coefficient are statistically significant. These good results imply a superior explanatory ability of the four-factor model. It can be clearly observed from Panel A that the alpha of the social security fund portfolio as a whole is positive, but not statistically significant, indicating that after the fund's investment risk is taken into account, the social security fund cannot obtain excess returns. The direct investment alpha is not statistically significant, but the entrusted investment alpha is significant at the $10 \%$ level with a value of $0.36 \%$. In other words, entrusted portfolios can achieve abnormal returns of $4.32 \%$ a year.

Panel B of Table 4 reports the results of entrusted investment fund risk-adjusted returns. It can be seen that entrusted investment fund companies perform differently. Boshi Fund, the South Fund, Zhaoshang Fund and Yifangda fund are able to obtain statistically significant excess yields, while the remaining funds cannot obtain abnormal returns. CICC's excess return is significantly negative at the $5 \%$ level. Among them, the highest excess return comes from the South Fund, with annual excess returns of 17.1, followed by Yifangda fund (9.56 percent), Zhaoshang Fund (9.12 percent) and Boshi Fund (5.65 percent).

The results in Table 4 show that the overall efficiency of the national social security 
fund investment is not high; only 40 percent of entrusted investment institutions are able to obtain excess returns. Overall, the efficiency of direct investment is lower than that of entrusted investment. The returns of entrusted investments are quite diverse; the South Fund's investment shows the highest level of efficiency, while CICC investment is the least efficient. 
Table 4

Four-factor risk-adjusted return

\begin{tabular}{|c|c|c|c|c|c|c|}
\hline \multirow[t]{2}{*}{ Panel A } & \multirow[b]{2}{*}{ alpha $(\%)$} & \multicolumn{3}{|c|}{ Direct operation-entrusted Investment } & \multirow[b]{2}{*}{$M O M$} & \multirow[b]{2}{*}{$\operatorname{Adj} . R^{2}$} \\
\hline & & $R M-R F$ & $S M B$ & $H M L$ & & \\
\hline \multirow{2}{*}{ Total } & 0.3137 & $0.956 * * *$ & $0.392 * * *$ & $-0.341 * * *$ & $0.234 * * *$ & 0.9648 \\
\hline & $(1.59)$ & $(50.78)$ & (10.74) & $(-6.76)$ & $(4.11)$ & \\
\hline \multirow{2}{*}{ Direct } & -0.25 & $1.20^{* * *}$ & 0.11 & -0.285 & -0.271 & 0.5954 \\
\hline & $(-0.243)$ & $(12.31)$ & $(0.583)$ & $(-1.08)$ & $(-0.918)$ & \\
\hline \multirow[t]{2}{*}{ Entrusted } & $0.360^{*}$ & $0.949 * * *$ & $0.403 * * *$ & $-0.359 * * *$ & $0.257 * * *$ & 0.9626 \\
\hline & $(1.78)$ & (49.13) & $(10.75)$ & $(-6.91)$ & (4.39) & \\
\hline \multicolumn{2}{|l|}{ Panel B } & \multicolumn{3}{|c|}{ Entrusted investment Return } & & \\
\hline Boshi & $0.471^{* *}$ & $0.896^{* * *}$ & 0.012 & $-0.240 * * *$ & $0.139 * *$ & 0.9127 \\
\hline Fund & $(2.17)$ & $(32.40)$ & $(0.14)$ & $(-2.90)$ & $(2.24)$ & \\
\hline Guotai & 0.487 & $1.001 * * *$ & $0.260^{* *}$ & $-0.405 * * *$ & 0.256 & 0.8134 \\
\hline Fund & $(0.88)$ & $(17.89)$ & $(2.20)$ & $(-2.88)$ & $(1.35)$ & \\
\hline Huaxia & 0.676 & $0.977 * * *$ & $0.387 * * *$ & $-0.520 * * *$ & $0.428 * *$ & 0.7901 \\
\hline Fund & $(1.15)$ & $(34.83)$ & $(10.47)$ & $(-5.61)$ & $(2.55)$ & \\
\hline Jiashi & 0.504 & $0.885 * * *$ & 0.111 & $-0.373 * * *$ & $0.284 * *$ & 0.8665 \\
\hline Fund & $(1.37)$ & $(24.86)$ & $(1.60)$ & $(-4.04)$ & $(2.67)$ & \\
\hline Nanfang & $1.425^{* *}$ & $1.369 * * *$ & 0.071 & 0.113 & $0.752 * *$ & 0.8765 \\
\hline Fund & $(2.03)$ & $(18.88)$ & $(0.60)$ & $(0.34)$ & $(2.66)$ & \\
\hline Penghua & 0.291 & $0.919 * * *$ & $0.291 * * *$ & $-0.429 * * *$ & $0.547 * * *$ & 0.8795 \\
\hline Fund & $(0.986)$ & $(31.45)$ & (3.68) & $(-5.21)$ & $(8.54)$ & \\
\hline Yifangda & $0.797 *$ & $0.900 * * *$ & $0.379 * * *$ & $-0.785 * * *$ & $0.290 * * *$ & 0.8272 \\
\hline Fund & $(1.75)$ & $(43.81)$ & $(9.48)$ & $(-21.45)$ & $(4.09)$ & \\
\hline Changsheng & 0.279 & $0.919 * * *$ & $0.342 * * *$ & $-0.416^{* *}$ & 0.293 & 0.7494 \\
\hline Fund & $(0.47)$ & $(14.87)$ & (3.12) & $(-2.26)$ & (1.29) & \\
\hline Zhaoshang & $0.76^{*}$ & $1.007 * * *$ & $0.097^{*}$ & $-0.406 * * *$ & 0.180 & 0.7766 \\
\hline Fund & $(1.81)$ & $(29.93)$ & $(1.71)$ & $(-4.66)$ & $(1.49)$ & \\
\hline Zhongjin & $-1.89^{* *}$ & $1.096 * * *$ & 0.281 & -0.347 & -0.001 & 0.6659 \\
\hline Corparation & $(-2.21)$ & $(9.43)$ & $(1.25)$ & $(-1.48)$ & $(-0.01)$ & \\
\hline
\end{tabular}

$*, * *, * * *$ denote significance at the $10 \%, 5 \%, 1 \%$ levels, respectively. Value in brackets is the White method-adjusted robust $t$ value.

\subsection{Cause for differences in investment efficiency}

\subsubsection{Investment Style}

If the risk factor coefficients in Table 4 are statistically significant, we can infer information about the style of the social security fund's investment (Davis, 2001). The 
market portfolio coefficient factor of direct investment is 1.2 , which is significant at the $1 \%$ level. However, the remaining coefficient factors are not statistically significant; the market portfolio coefficient factor of entrusted investment is 0.949 , and the four factors are all statistically significant. This result suggests that direct investment prefers high-risk stocks but cannot obtain excess returns while entrusted investment funds prefer to vary investment scale and investment momentum to obtain excess returns. In addition, the South Fund's momentum factor is significantly positive, indicating that the South Fund has the "momentum effect", i.e. it follows the investment style of buying the winners and selling the losers. All risk factors in the Yifangda Fund are statistically significant, but the market factor coefficient is only 0.9, indicating an overall lower risk. Yifangda tends to invest in small companies with a low book-to-market value and to use momentum investment strategy. The Boshi Fund reveals low market risk, high momentum investment and a high book-to-market investment style. Simple investment styles, as well as the excess configuration of the high-risk stocks may be the reasons for the low efficiency of the social security fund investment.

\subsubsection{Asset Allocation}

The previous section already confirms that the CNSSF pursues two different investment styles and that they differ significantly in efficiency. Merton (1987) suggests in his theory that, due to the presence of market transaction costs and asymmetric information, the price may not be a complete reflection of all the information of the assets. If investors are able to tap inside market information, they can receive excess returns. Studies by Cremers and Petajisto (2009) and LuoRonghua et al. (2011) find that the initiative of the fund manager may open access to more inside market information and result in a better investment performance. This article draws on Amihud and Goyenko (2013) to measure the amount of inside market information (private information) involved in social security fund asset allocation. In addition, we used the Amihud and Goyenko (2013) method to study the relationship between the presence of private information in the social security fund and investment 
performance. Pollet and Wilson (2008) suggest that the depth and breadth of the fund's stock selection can significantly affect the investment performance of the fund. To clarify the role of private information on the social security fund investment return there is a need to control the risk of the portfolio (Beta), the breadth of asset allocation (Width) and the depth (Depth).

Table 5 shows the results of the comparison of the CNSSF portfolio asset allocation types. Panel A exhibits the average of the overall sample of the CNSSF and direct investment. The results indicate that access to private information of the overall sample is 0.438 , while that of direct investment is 0.398 , i.e., it is lower than the overall access to private information, and therefore lower than access to private information on the part of the entrusted companies. The average risk coefficient of direct investment stock is 1.03 , higher than the overall average. Direct investment indicators for both depth and breadth are below those of entrusted investment.

For a clearer comparison between direct investment and entrusted investment asset allocation differences, we subtracted the direct investment asset allocation indicator from the entrusted investment asset allocation indicator, and then used a t-test to test for statistical significance. Table 5, Panel B, shows that the entrusted investment's access to private information is significantly higher compared to direct investment at the 1-percent significance level. This shows that access to private information is greater for entrusted investment than direct investment, and that access to private information may achieve higher returns.

Secondly, from the aspect of the equity portfolio risk coefficient, the beta coefficient of Boshi Fund, Harvest Fund and the other four funds is significantly lower than that of direct investment. The equity portfolio's beta coefficient of Huaxia Fund, South Fund, and CICC is significantly higher than that of the direct investment portfolio. In addition, with the exception of the Guotai Fund, the disparity indicators of the rest of the fund's asset allocation depth is significantly higher than those of the direct investment portfolio, and the fund's asset allocation breadth indicators are significantly lower than those of the direct investment portfolio. These two indicators 
fully explain that the CNSSF entrusted investments are very concentrated, which may be one of the reasons for the low return from direct investment. 
Table 5: Asset Allocation: Comparison

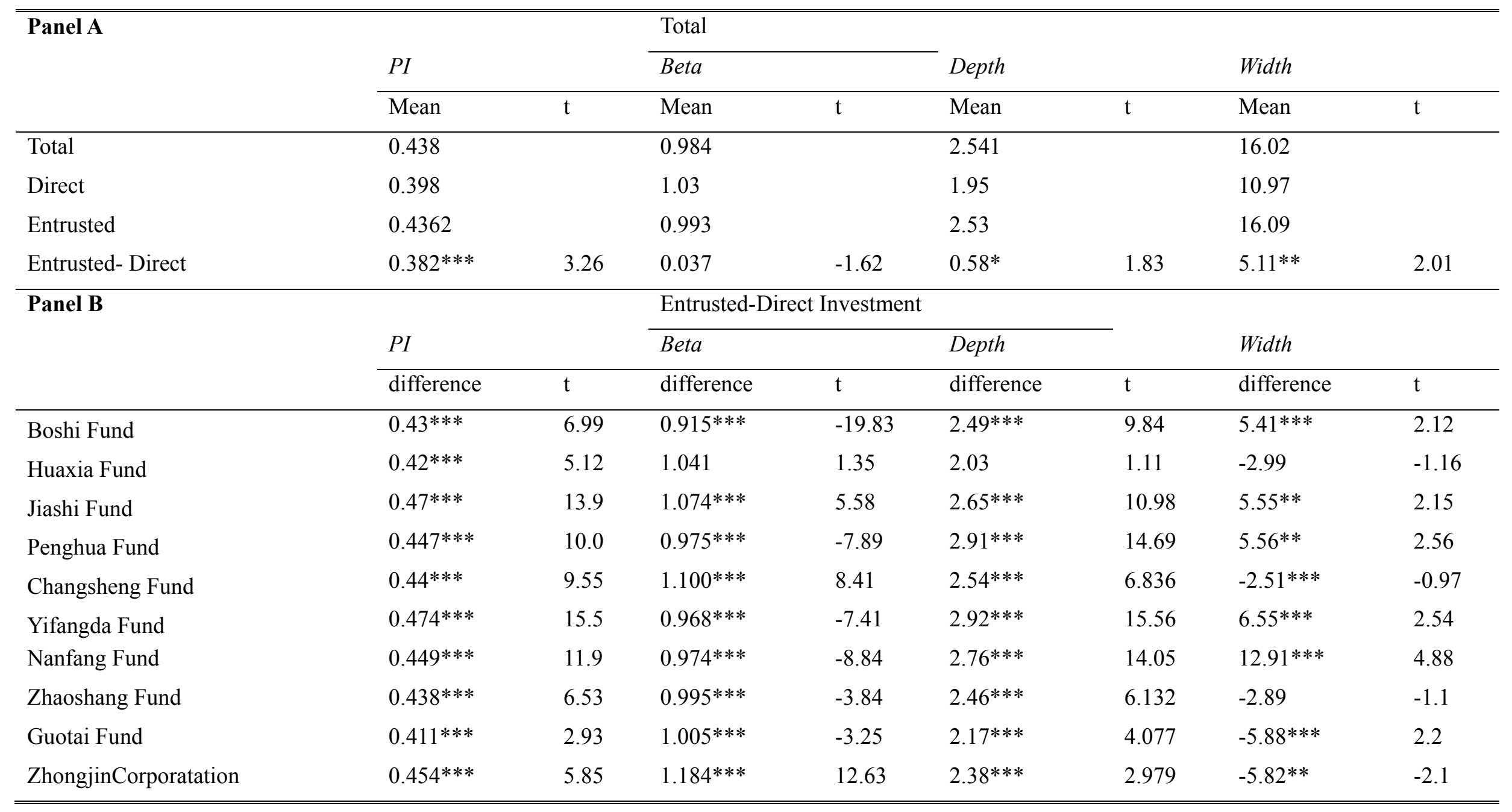

**,**,*** denote significance at $10 \%, 5 \%, 1 \%$ level respectively. 


\subsubsection{Regression Results}

Furthermore, we used a panel data regression analysis to test for a link between access to private information and social security fund investment return. In reference to models by Pollet and Wilson (2008), Amihud and Geyonko (2013), which are designed to control for fund size, fund family size and other factors, we have developed the following empirical model to verify the significance of the social security fund performance factors.

$$
\begin{aligned}
\text { Return }_{i t} & =\alpha+\beta_{1} P I_{i t}+\beta_{2} \text { Beta }_{i t}+\beta_{3} \text { Width }_{i t}+\beta_{4} \text { Depth }_{i t}+\beta_{5} \text { Size }_{i t} \\
& +\beta_{6} \text { Fsize }_{i t}+\beta_{7} P I^{*} D I_{i t}+\text { Year }+u_{i}+\varepsilon_{i t}
\end{aligned}
$$

Among them, Return ${ }_{i t}$ represents the weighted yield of fund $i$ in quarter $t, P I$ represents the average weighted access to private information of the portfolio, Beta represents the average portfolio risk coefficient. Width and Depth, respectively, represent the breadth and depth of the portfolio. Size represents the total market capitalization of the portfolio, Fsize is the total assets of the fund family, DI is a dummy variable; 1 if the sample is the portfolio of the direct investment, 0 otherwise. Year is a time dummy variable. Before conducting empirical research, we first ran a variable multi-collinearity test. The variance inflation factor (VIF) values are below 2.5, which means there is no multi-collinearity in the regression results.

The data used in this paper is quarterly unbalanced panel data. There are two ways to conduct an unbalanced panel data regression: fixed effects regression and random effects regression. The fixed effects regression assumes that the individual effects of the sample do not change with time, i.e., one can use the first-order differential or centralization to eliminate the individual effects, and then conduct an OLS regression to determine the coefficient. A random effects regression assumes that the individual effects cannot be observed over time, and it is possible to run a GLS regression to obtain the coefficient. We have taken into account that the individual effects, such as corporate culture of the social security funds which cannot be observed, may have an important impact on investment performance. In order to avoid endogeneity problems 
by omitting variables, we used a fixed effects model for our analysis and run a Hausman test as a robustness check.

Table 6 shows that all regressions from the Hausman test are significant at the 5 percent level. The table also reports the fixed effects regression results and the White robust standard error-adjusted t-values. Column (1) shows the results of controlling for the fund family factors; private information (PI) and fund investment income are significantly positively related at the 5-percent level. The resulting economic implications for private information are that a one-unit increase results in an increase of the funds' return by 0.36 percent. Our results thus confirm the findings of Amihud and Goyenko (2013) and Merton (1987). When controlling for other variables, the contribution of private information to the fund's investment return increases. In Model (6), for example, private information is positively statistically significant at the 10percent level. The portfolio's Beta coefficient and fund return show a significant positive correlation with each other.

In addition, asset configuration depth and investment return are not statistically significantly correlated, while breadth and investment return show a significant negative correlation. This means that a broader investment scope results in a lower return, the same conclusion as adapted by Kacperczyk (2005), Nieuwerburgh and Veldkamp (2010). The fund's investment also reveals a significant diminishing scale, for every 1 percent increase in scale; investment return is reduced by 4.68 percent. The PI * DI variable coefficient is negative, indicating that the return on direct investment is lower than the return on entrusted investment The coefficient however, is not statistically significant, indicating that direct investment and entrusted investment do not significantly differ from each other.

Results in Table 6 confirm that the fund's investment return is significantly related to the private information of fund asset allocation, the risk factor and dispersion. After controlling for other factors, there is no significant difference between the social security fund's direct investment and entrusted investment returns. 


\begin{tabular}{|c|c|c|c|c|c|c|}
\hline & & Seasonly & urn & & & \\
\hline & (1) & (2) & (3) & (4) & (5) & (6) \\
\hline$P I$ & $0.360 * *$ & $0.458 * * *$ & $0.470 * * *$ & $0.498 * * *$ & $0.387 * *$ & $0.477^{*}$ \\
\hline & $(2.80)$ & $(3.31)$ & (3.29) & $(3.29)$ & $(2.27)$ & $(1.79)$ \\
\hline Beta & & $0.255^{* *}$ & $0.256^{* *}$ & $0.274 * * *$ & $0.244^{* *}$ & $0.246^{* *}$ \\
\hline & & (2.69) & $(2.70)$ & $(2.87)$ & $(2.44)$ & $(2.43)$ \\
\hline Depth & & & -0.00327 & -0.00596 & -0.00833 & -0.00837 \\
\hline & & & $(-0.25)$ & $(-0.43)$ & $(-0.60)$ & $(-0.60)$ \\
\hline Width & & & & $-0.00283 *$ & $-0.00453 * *$ & $-0.00459 * *$ \\
\hline & & & & $(-2.07)$ & $(-2.69)$ & $(-2.71)$ \\
\hline Size & & & & & $-0.0466^{* *}$ & $-0.0468^{* *}$ \\
\hline & & & & & $(-2.19)$ & $(-2.23)$ \\
\hline$P I^{*} D I$ & & & & & & -0.0977 \\
\hline & & & & & & $(-0.43)$ \\
\hline FSize & $0.0314^{*}$ & $0.0393 * *$ & $0.0398 * *$ & $0.0540 * * *$ & $0.0708 * * *$ & $0.0714 * * *$ \\
\hline & $(1.77)$ & $(2.24)$ & $(2.36)$ & $(3.38)$ & $(3.29)$ & $(3.39)$ \\
\hline Cons & $-0.415^{*}$ & $-0.799 * *$ & $-0.803 * *$ & $-0.942 * * *$ & $-0.731 * *$ & $-0.737 * *$ \\
\hline & $(-1.84)$ & $(-2.79)$ & $(-2.82)$ & $(-3.38)$ & $(-2.49)$ & $(-2.50)$ \\
\hline Cluster & Yes & Yes & Yes & Yes & Yes & Yes \\
\hline$N$ & 493 & 493 & 493 & 493 & 493 & 493 \\
\hline$R^{2}$ & 0.031 & 0.056 & 0.057 & 0.063 & 0.072 & 0.072 \\
\hline Hausman & $8.58 * *$ & $11.16^{* *}$ & $10.94 * *$ & $12.93 * *$ & $17.42 * * *$ & $16.37 * *$ \\
\hline Prob $>$ chi 2 & 0.0137 & 0.0109 & 0.0273 & 0.0240 & 0.0078 & 0.0219 \\
\hline
\end{tabular}

$*, * *, * * *$ denote significance at the $10 \%, 5 \%, 1 \%$-levels respectively. Value in brackets is the White method-adjusted robust $t$ value.

\subsubsection{Endogenous analysis}

Since we are not able to observe the correlation between the individual fund characteristics using investment performance, we use the fixed-effect model to reduce the endogeneity problem caused by omitting variables. However, the allocation of private information may still evoke endogeneity problems because institutional investors' portfolios may cause a "herding" effect (Patrick and Strickland, 2002; Liu 
and Tang, 2011).The stock price may react to information timely, increasing prices may attract market attention, thus private information may become public information.; so private information may be affected by the stock price. This establishes a reverse causal relationship between fund return and private information. To solve this endogenous problem, we used a two-stage instrumental variable method for our analysis.

The difficulty lies in that the two-stage instrumental variable regression needs to select the appropriate instrumental variables that meet two conditions. Firstly, instrumental variables must be closely related to private information about the configuration of social security fund assets. Secondly, instrumental variables and the investment return must not be related. From the fund company's R\&D point of view, we selected the average amount of private information of the fund's equity portfolio as the instrumental variable. The fund company's research department will likely share the research reports within the company. So the social security fund portfolio, like other funds, will also be affected by R\&D information inside the company. Therefore, the private information of the social security fund portfolio should be associated with the company's average amount of private information (Nanda et al., 2004). For example, every Chinese mutual fund company has a meaningful research department for intensive research. However, they also buy analysis reports from other brokers, thus sharing information with other mutual fund companies. Secondly, the correlation between the average amount of fund companies' private information and a social security fund portfolio's return must not be high. In this paper, we use an Anderson LR test to check whether the instrumental variables exhibit a weak instrument problem, a Cragg-Donald Wald test to check whether the instrumental variables exhibit an under-identification problem, and a Sargan test to identify a potential over-identification problem of the instrumental variables.

Table 7 shows the results of a two-stage fixed effects regression. For robustness considerations, we use the mean and the median of the fund's average amount of 
private information as the social security fund portfolio's private information instrumental variables. A Hausman test shows that the instrumental variable model is superior to non-instrumental variable models, indicating the presence of a private information endogeneity problem. The results of the first stage regression show that the mean and the median of private information are positively correlated with the private information of the CNSSF, and are significant at the 1-percent and 5-percent levels, respectively. Secondly, an Anderson LR test is significant at the 1-percent level, indicating that there is no weak instrumental variable problem. The Cragg-Donald Wald test and the Sargan test indicate that there is no under- or over-identification problem for the instrumental variable. Furthermore, the above test results show that the selection of the instrumental variables in this article is reasonable. Hence, it is appropriate to use the two-stage instrumental variable method for analysis.

The second-stage regression results point out that private information and fund investment returns have a significant positive relationship. PI * DI is statistically negatively significant, which illustrates that the return of direct investment decreases with greater access to private information. This is consistent with the previous statistical results that private information of direct investment is significantly lower than that of entrusted investment. The results of the remaining variables are fundamentally the same as in Table 6, confirming that the two-stage fixed-effects regression results are robust. 


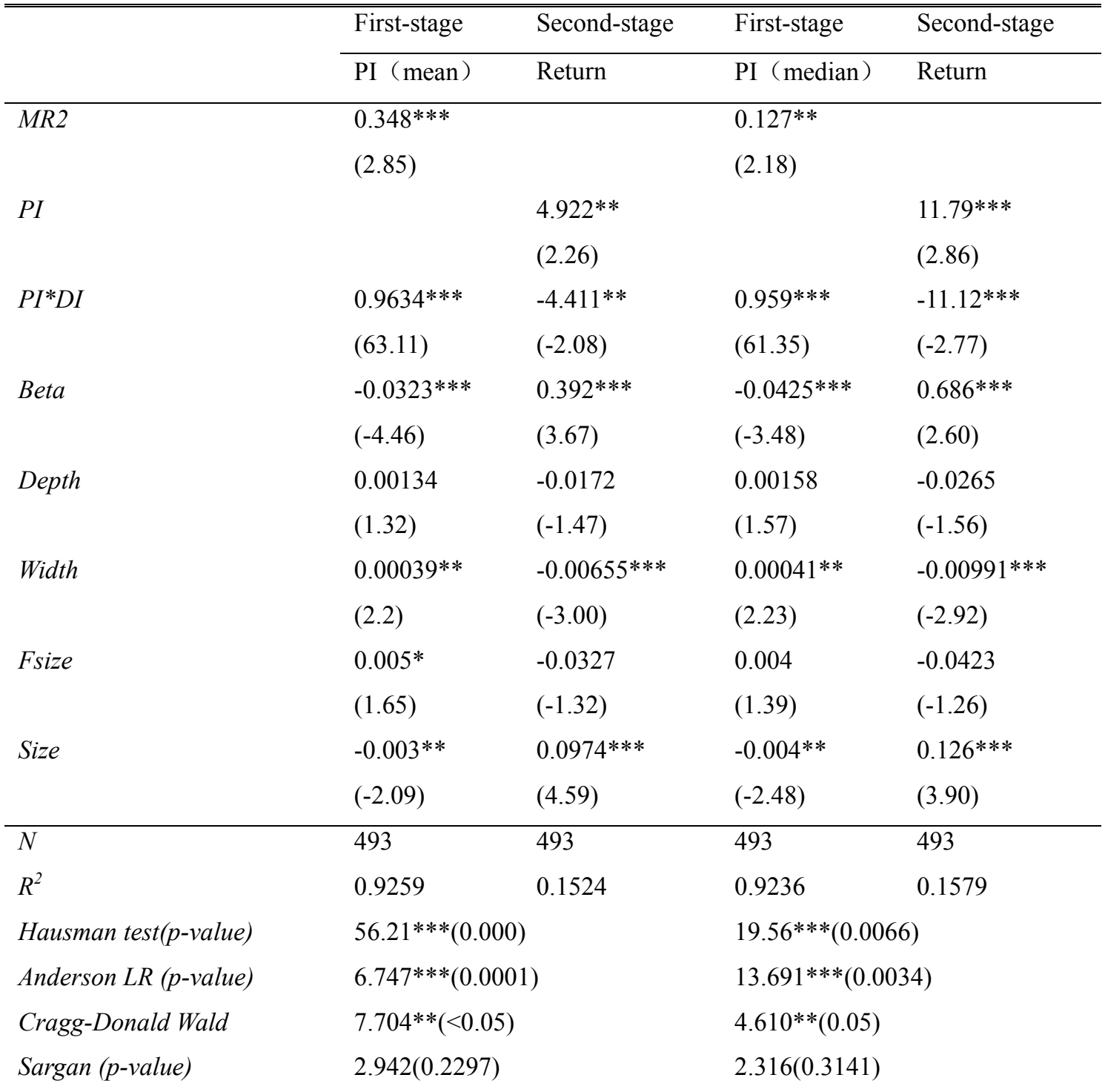

$*, * *, * * *$ denote significance at the 10-percent, 5-percent and 1-percent levels, respectively. Value in brackets is robust White method-adjusted $t$ value. An Anderson LR test is used for the instrument under-identification problem. If Anderson LR is significant, the variable is correlated with endogenous variables. Cragg-Donald test issued for the weak-identification problem. If CraggDonaldis not significant, instrument variables are highly correlated with the endogenous variable. The Sargan test is used for the over-identification problem. If it is not significant, there is no overidentification problem and it is not correlated with the residuals.

\subsubsection{Robustness check}

For robustness considerations, this paper also uses the Fama and French (1993) threefactor model regression. The results are consistent with the four-factor model. In 
addition, taking into account the fact that the yield data does not completely follow a normal distribution, we use the self-help method which results in a robust $t$ value. The results do not change when conducting this test; hence the results in the regressions are robust.

\section{Further studies}

CNCSSF, as a special institutional investor, should have a market-stabilizing function. As indicated in Figure 1, the CNSSF and the stock market have a lead-lag relationship, and CNCSSF direct investment returns are significantly lower than those of entrusted investment. Does direct investment stabilize the market and have a weaker investment return as a result? To answer this question, it is necessary to control for the key factors that affect stock market volatility. We drew on He et al. (2007), using the following model to investigate the CNSSF's market-stabilizing function.

$$
\begin{aligned}
\text { Vol }_{t}= & \alpha+\beta_{1} \text { Flow }_{t}+\beta_{2} \text { Tover }_{t}+\beta_{3} \text { Nipo }_{t}+\beta_{4} \text { Finan }_{t}+\beta_{5} \text { Fvol }_{t} \\
& +\beta_{7} \text { Mrtn }+\beta_{7} \text { Mfrtn }+\varepsilon_{t}
\end{aligned}
$$

Vol is the volatility of the stock market; we use CSI (Shanghai and Shenzhen Composite Index $)^{2}$ quarter-over-quarter standard deviations of the daily yield and two range indicators (max-min) to measure Vol. Tover is the average quarterly turnover rate of the securities market measuring market investor sentiment; the greater the index, the more active the market. Nipo represents the number of IPOs in the quarter. Finan represents the IPO financing amount. Fvol is the volatility of foreign markets. Following Sheng et al. (2008), we use the Hang Seng Index in Hong Kong as an alternative variable most closely associated with China's market in this paper. Mrtn and Mfrtn respectively denote the average yield of the CSI and the Hang Seng Index.

Flow is the social security fund's liquidity ratio. Referring to Sirri and Tufano (1998) and Huang et al. (2007) regarding the definition of the fund's liquidity, and assuming

\footnotetext{
${ }^{2}$ The CSI index is a capitalization-weighted stock market index designed to replicate the performance of stocks traded in the Shanghai and Shenzhen stock exchanges.
} 
that the cash flow takes place at the end of the term, Flow is defined as follow:

$$
\text { Flow }_{t}=\left(M v_{t}-\left(1+r_{t}\right) M v_{t-1}\right) / M v_{t-1}
$$

$M v$ is the scale of the market value of the social security fund and $r$ is the social security fund investment yield. Flow ratios take into account the scale factors of the social security fund, thus depicting the quarterly liquidity of the social security fund. If Flow is greater than 0 , the social security funds are funneling money into the stock market; Conversely, when Flow is smaller than 0, the social security funds are moving money out of the stock market.

The robustness regression results are shown in Table 7 . It can be easily observed from the overall sample that the CNSSF significantly reduces market volatility. Every 1percent increase in CNSSF's investment decreases the volatility of the market index by 0.114 percent. This shows that the stabilization function of the CNSSF is highly significant. In addition, the CNSSF direct investment coefficient is significantly negative at the 5-percent level, 2.8 times the entrusted investment coefficient. The economic implications of this result are that with every 1-percent increase in CNSSF direct investment, the CNSSF's effect on market stability is 2.8 times better than that of entrusted investment, which makes its market stabilization function significantly higher than that of entrusted investment. In addition, the results' robustness points out that direct investment is significant at the 10-percent level, while the entrusted investment coefficient is negative, but not statistically significant. This further verifies that direct investment has a stronger stabilization function.

As a further robustness check, we also follow the advice of Zheng (1999), assuming that capital inflow takes place at the beginning of the term and we repeat the previous regression. The results are almost identical with those in Table 8, indicating that the results of this paper are robust. 


\begin{tabular}{|c|c|c|c|c|c|c|}
\hline & \multicolumn{3}{|c|}{ Volatility } & \multicolumn{3}{|c|}{ Return Range } \\
\hline & Total & Direct & Entrusted & Total & Direct & Entrusted \\
\hline \multirow[t]{2}{*}{ Flow } & $-0.114 * *$ & $-0.377 * *$ & $-0.135^{* *}$ & -0.397 & $-1.59 *$ & -0.419 \\
\hline & $(-2.29)$ & $(-2.49)$ & $(-2.06)$ & $(-1.32)$ & $(-1.73)$ & $(-1.08)$ \\
\hline \multirow[t]{2}{*}{ Tover } & $0.475^{* * *}$ & $0.362 * *$ & $0.519 * * *$ & $3.19 * * *$ & $2.70 * * *$ & $3.33 * * *$ \\
\hline & $(3.40)$ & $(2.57)$ & $(3.66)$ & $(4.55)$ & $(3.42)$ & $(4.68)$ \\
\hline \multirow[t]{2}{*}{ Nipo } & -0.186 & $-0.366^{*}$ & -0.182 & $-2.45^{*}$ & $-2.95 * *$ & $-2.58 *$ \\
\hline & $(-0.78)$ & $(-1.85)$ & $(-0.74)$ & $(-1.77)$ & $(-2.31)$ & $(-1.95)$ \\
\hline \multirow[t]{2}{*}{ Finan } & 0.0958 & 0.0988 & 0.0938 & 0.555 & 0.572 & 0.547 \\
\hline & $(1.57)$ & $(1.66)$ & $(1.53)$ & $(1.61)$ & (1.67) & $(1.58)$ \\
\hline \multirow[t]{2}{*}{ Fvol } & $0.323 * * *$ & $0.319 * * *$ & $0.322 * * *$ & 0.876 & 0.872 & 0.864 \\
\hline & $(3.32)$ & $(3.43)$ & $(3.29)$ & $(1.60)$ & $(1.62)$ & $(1.58)$ \\
\hline \multirow[t]{2}{*}{ Mrtn } & -0.218 & -0.155 & -0.242 & -1.981 & -1.706 & -2.061 \\
\hline & $(-0.58)$ & $(-0.43)$ & $(-0.62)$ & $(-0.92)$ & $(-0.83)$ & $(-0.94)$ \\
\hline \multirow[t]{2}{*}{ Fmrtn } & $-1.083^{*}$ & $-1.132 *$ & $-1.100 *$ & $-7.396 * *$ & $-7.450 * *$ & $-7.535 * *$ \\
\hline & $(-1.91)$ & $(-2.00)$ & $(-1.94)$ & $(-2.19)$ & $(-2.22)$ & $(-2.22)$ \\
\hline \multirow[t]{2}{*}{ cons } & $0.0102 * * *$ & $0.0105 * * *$ & $0.00985 * * *$ & $0.0582 * * *$ & $0.0606 * * *$ & $0.0568 * * *$ \\
\hline & $(4.16)$ & $(4.53)$ & $(3.99)$ & $(3.86)$ & $(4.17)$ & $(3.77)$ \\
\hline$N$ & 33 & 33 & 33 & 33 & 33 & 33 \\
\hline Adj. $R^{2}$ & 0.718 & 0.724 & 0.709 & 0.661 & 0.673 & 0.655 \\
\hline
\end{tabular}

$*, * *, * * *$ denote significance at the 10-percent, 5-percent, 1-percent levels, respectively. The value in brackets is the robust White method-adjusted t value.

\section{Conclusion}

Our in-depth research on the investment efficiency of the two types of investment carried out by the Chinese National Social Security Fund shows that, on the whole, CNSSF investment efficiency is not high and cannot achieve excess market returns. More specifically, all entrusted investment portfolio funds combined do achieve excess annual returns of 4.32 percent, while direct investment portfolio funds do not. At the same time, entrusted investments differ greatly in their return performance; only 40 percent of the fund companies are able to obtain abnormal returns after being given enough compensation for their risk in the market. This article also finds that private information and investment returns are significantly positively correlated, and 
that the amount of private information involved in direct investment is significantly lower than that involved in entrusted investment, explaining the inefficiency of direct investment. Our further research shows that the CNSSF has an important marketstabilizing function, with the market-stabilizing function of direct investment being almost three times that of entrusted investment.

This article has three main results. Firstly, the CNSSF stock market investment cannot achieve above normal returns but it has a strong market-stabilizing function. In addition, 6 in 10 entrusted investment companies do not show a superb ability to invest in the stock market, resulting in the CNSSF not meeting its "value-added" requirements. Therefore, China's social security system faces a gargantuan pension gap that is extremely perilous for an aging population. How to improve the entrusted companies' investment efficiency has become a pressing issue for the CNSSF. Firstly, the investment of CNSSF should encourage competition. The Chinese National Council for Social Security Fund should therefore reduce or terminate investments into the investment fund companies with the weakest performance and allocate additional funds to better performing companies. Secondly, private information plays an important role for social security funds' returns. CNSSF has an indisputable advantage in terms of financial strength and information channels. In order to protect the interests of investors and the unbiased market, regulatory agencies need to monitor the social security funds' investment behavior in China to avoid insider trading, market manipulation and other violations of the market. Thirdly, China needs to construct a multi-layered wealth management market, which requires relatively independent institutional investors. These institutional investors' financial innovation as well as R\&D should be supported by the social security fund to obtain greater excess returns. 


\section{References}

[1] Amihud, Y. and R. Goyenko, 2013, "Mutual Fund's R ${ }^{2}$ as Predictor of Performance", Review of Financial Studies 26 (3), 667-694.

[2] Bauer, R., M. Cremers, and R. Frehen, 2010, "Pension Fund Performance and Costs: Small is Beautiful", Maastricht University Working Paper.

[3] Beebower, G. and G. Bergstrom, 1977, "A Performance Analysis of Pension and ProfitSharing Portfolios: 1966-1975”, Financial Analysts Journal 33 (3), 31-42.

[4] Blake, D., B. Lehmann, and A. Timmermann, 1999, "Asset Allocation Dynamics and Pension Fund Performance", Journal of Business 72 (4), 429-461.

[5] Bohl, M. T. and J. J. Brzeszczynski, 2006, "Do Institutional Investors Destabilize Stock Prices? Evidence from an Emerging Market", Journal of International Financial Markets, Institutions and Money 16 (4), 370-383.

[6] Brands S., S. J. Brown, and D. R. Gallagher, 2006, "Portfolio Concentration and Investment Manager Performance", International Review of Finance 5 (3-4), 149-174.

[7] Brinson, G., L. Hood, and G. Beebower, 1986, "Determinants of Portfolio Performance", Financial Analysts Journal 47 (3), 231-262.

[8] Busse, J., A. Goyal, and S. Wahal, 2010, "Performance Persistence in Institutional Investment Management", Journal of Finance 65 (2), 765-790.

[9] Cai, Q. F. and Y. Y. Song, 2010, "Can the Hyper-normal Development of Institutional Investors Stabilize the Market? Leapfrog Development of China's Fund Industry", Economic Research Journal (1), 90-101.

[10] Carhart, M. M., 1997, "On Persistence in Mutual Fund Performance", Journal of Finance 52 (1), 57-82.

[11] Chen, J., H. Hong, M. Huang, and J. D. Kubik, 2004, "Does Fund Size Erode Mutual Fund Performance? The Role of Liquidity and Organization", American Economic Review 94 (5), 1276 1302.

[12] Coggin, T., F. Fabozzi, and S. Rahman, 1993, "The Investment Performance of U.S. Equity Pension Fund Managers: An Empirical Investigation”, Journal of Finance 48 (3), 1039-1055.

[13] Cremers, M. and A. Petajisto, 2009, "How Active Is Your Fund Manager? A New Measure That Predicts Performance", Review of Financial Studies 22 (9), 3329-3365.

[14] Davis, J. L., 2001, "Mutual Fund Performance and Manager Style", Financial Analysts Journal 57 (1), 19-27.

[15] Del Guercio, D. and Tkac, P. A., 2002, "The Determinants of the Flow of Funds of Managed Portfolios: Mutual Funds versus Pension Funds", Journal of Financial and Quantitative Analysis 37 (4), 523-557.

[16] Elton, J., M. Gruber, and C. Blake, 2006, "Participant Reaction and the Performance of Funds Offered by 401(k) Plans", Journal of Financial Intermediation 16 (2), 249-271.

[17] Fama, E. F. and K. R. French, 1993, "Common Risk Factors in the Returns on Stocks and Bonds", Journal of Financial Economics 33 (1), 3-56.

[18] Gregory, A. and I. Tonks , 2004, "Performance of Personal Pension Schemes in the UK" 
UBS/FMG Discussion Paper, No. 486, March 2004.

[19] He, J., J. B. He, X. Wang, and W. L. Zhai, 2007, "Do Institutional Investors Stabilize the Stock Market: Empirical Evidence from China", Management World (8), 35-42.

[20] Huang J., K. D. Wei, and H. Yan, 2007, "Participation Costs and the Sensitivity of Fund Flows to Past Performance", Journal of Finance 62 (3), 1273-1311.

[21] Ippolito, R. and J. Turner, 1987, “Turnover, Fees and Pension Plans Performance”, Financial Analysts Journal 43 (6), 16-26.

[22] Kacperczyk, M., C. Sialm, and L. Zheng, 2005, "On the Industry Concentration of Actively Managed Equity Mutual Funds", Journal of Finance 60 (4), 1983-2011.

[23] Lakonishok, J. A., A. Shleifer, and R. W. Vishny., 1992, "The Structure and Performance of the Money Management Industry", Brookings Papers on Economic Activity, 339-391.

[24] Levy, A. and M. Livingston, 1995, "The Gains from Diversification Reconsidered: Transaction Costs and Superior Information", Financial Markets, Institutions, and Instruments (4), $1-60$.

[25] Liao L., B. B. Liu, and J. L. Li, 2008, "On the Moral Hazards, Information Revelation and Market Efficiency: Evidence from the Split-share Reform in China", Journal of Financial Research (4), 146-160.

[26] Liu, Y. Z. and D. P. Tang, 2011, "The Market Reaction of Social Security Fund Investment Information: Based on the Data from China Capital Market", Journal of Audit \& Economics (4), 3-13.

[27] Luo, R. H., W. Lan, and Y. H. Yang, 2011, "Does Active Management Improve Mutual Fund's Performance?", Journal of Financial Research (10), 127-139.

[28] Merton, R. C., 1987, "A simple model of capital market equilibrium with incomplete Information", Journal of Finance 42 (3), 483-510.

[29] Nanda, V., Z. J. Wang, and L. Zheng, 2004, "Family Values and the Star Phenomenon: Strategies of Mutual Fund Families", Review of Financial Studies 17(3), 667-698.

[30] Nieuwerburgh, V. S. and L. Veldkamp, 2010, "Information Acquisition and Under Diversification", Review of Economic Studies 77 (2), 779-805.

[31] Patrick J. D. and D. Strickland, 2002, "Who Blinks in Volatile Markets, Individuals or Institutions?", Journal of Finance 57 (5), 1923-1949.

[32] Pollet, J. and M. Wilson, 2008, "How Does Size Affect Mutual Fund Behavior?" Journal of Finance 63 (6), 2941-2969.

[33] Sheng, J. F., Y. Deng, and D. J. Tang, 2008, "Research on the Market Effect of the Institute Investors", Journal of Financial Research (9), 143-151.

[34] Shen, Y., Zhao Jingmei, He Xin, 2013, "Undisclosed information in Mutual Fund: Unobserved Trading and Investmen return", Management World (8), 55-66.

[35] Sirri, E. R. and P. Tufano, 1998, "Costly Search and Mutual Fund Flows", Journal of Finance 53 (5), 1589-1622.

[36] Thomas, A. and I. Tonks, 2001, "Equity Performance of Segregated Pension Funds in the UK", Journal of Asset Management 4 (1), 321-343.

[37] Teoh, S. H., Y. G. Yang, and Y. Zhang, 2009, "R-square and market efficiency", Working Paper.

[38] Tonks, I., 2005, "Performance Persistence of Pension-Fund Managers", Journal of Business 
$78(5), 1917-1942$.

[39] Wang, W., 2010, "The Investment Performance Analysis of China's Equity Pension Fund", Fudan University Master Thesis.

[40] Wermers, R., 2000, "Mutual Fund Performance: An empirical decomposition into Stock Picking Talent, Style, Transaction Costs, and Expenses", Journal of Finance 55 (4), 1655-1703.

[41] Wermers, R., 2003, "Is Money Really Smart? New Evidence on the Relation between Mutual Fund Flows, Manager Behavior, and Performance Persistence", Working Paper.

[42] Xiao, J. and J. Shi, 2011, "Historical Performance and Fund Flows: Does "Redemption Anomaly" Exist in China's Open-end Fund Market?" Economic Research Journal (1), 112-125.

[43] Zheng, L., 1999, "Is Money Smart? A Study of Mutual Fund Investors' Fund Selection Ability", Journal of Finance 54 (3), 901-933. 